\title{
BIBLIOGRAFIA PUBLIKACJI PROFESORA DR. HAB. PIOTRA PIOTROWSKIEGO
}

$\mathrm{Na}$ stronie internetowej Piotra Piotrowskiego (www.amu.edu.pl/ piotrpio) zamieszczona była starannie przez niego opracowana i regularnie uaktualniana bibliografia. Data ostatniej aktualizacji to 31 grudnia 2014 roku. Przedrukowujemy ją, zredagowaną, uzupełnioną o brakujące informacje i najnowsze publikacje, które już się ukazały, bądź są opracowywane.

\section{KSIĄŻKI AUTORSKIE}

Metafizyka obrazu. O teorii sztuki i postawie artystycznej Stanisława Ignacego Witkiewicza, Poznań: Wydawnictwo Naukowe UAM, 1985, ss. 130 .

Stanistaw Ignacy Witkiewicz, Warszawa: Krajowa Agencja Wydawnicza, 1989, ss. 167.

Dekada: o syndromie lat siedemdziesiatych, kulturze artystycznej, krytyce, sztuce - wybiórczo i subiektywnie, Poznań: Obserwator, 1991, ss. 87.

Artysta między rewolucją i reakcją. Studium z zakresu etycznej historii sztuki awangardy rosyjskiej, Poznań: Wydawnictwo Naukowe UAM, 1993, ss. 170.

W cieniu Duchampa. Notatki nowojorskie, Poznań: Obserwator, 1996, ss. 163.

Znaczenia modernizmu. W stronę historii sztuki polskiej po 1945 ro$k u$, Poznań: Dom Wydawniczy Rebis, 1999, ss. 289 (drugie wydanie: 2011).

Awangarda $w$ cieniu Jalty. Sztuka w Europie Środkowo-Wschodniej, 1945-1989, Poznań: Dom Wydawniczy Rebis, 2005, ss. 502. Wydanie angielskie: In the Shadow of Yalta. Art and the Avant-garde in Eastern Europe, 1945-1989, London: Reaktion Books, 2009, ss. 489; wydanie chorwackie: Avangarda u sjeni Jalte. Umjetnost Srednjoistocne Europe 
u razdoblju 1945-1989, Zagreb: Institut za Povijest Umjetnosti, 2011, ss. 487.

Sztuka według polityki. Od Melancholii do Pasji, Kraków: Uniwersitas, 2007, ss. 259.

Agorafilia. Sztuka i demokracja w postkomunistycznej Europie, Poznań: Rebis, 2010, ss. 300; wydanie angielskie: Art and Democracy in Post-Communist Europe, London: Reaktion Books, 2012, ss. 312.

Muzeum krytyczne, Poznań: Rebis, 2011, ss. 167; wydanie serbskie: Kritcki Muzej, Beograd: Evropa Nostra/ Centar za muzeologiju i heritologiju Univerziteta u Beogradu, 2013, ss. 147.

KSIĄŻKI I CZASOPISMA REDAGOWANE, KATALOGI WYSTAW

Galeria odNOWA, 1964-1969, Poznań: Muzeum Narodowe, 1993, ss. 99 [kat. wystawy; red. i współautorstwo]

Odwilż. Sztuka ok. 1956, Poznań: Muzeum Narodowe, 1996, ss. 316 [kat. wystawy; red. i współautorstwo]

Jarosław Kozłowski: Przestrzenie czasu/Spaces of Time, Poznań: Muzeum Narodowe, 1997, ss. 92 [kat. wystawy; red. i współautorstwo].

„Artium Quaestiones”, Poznań: Wydawnictwo Naukowe UAM, [współredakcja z Wojciechem Suchockim (pocz. także z Konstantym Kalinowskim) oraz bardzo często współautorstwo]: VIII (1997) ss. 198, IX (1998) ss. 237 , X (2000) ss. 307, XI (2000) ss. 350, XII (2001) ss. 469, XIII (2002) ss. 371, XIV (2003) ss. 392, XV (2004) ss. 288, XVI (2005) ss. 314, XVII (2006), ss. 429, XVIII, ss. 328, XIX, ss. 353, XX, ss. 256.

Zofia Kulik: Od Syberii do Cyberii / From Siberia to Cyberia, Poznań: Muzeum Narodowe, 1999, ss. 147 [kat. wystawy; red. i współautorstwo].

Grenzen überwinded. Festschrift für Adam S. Labuda zum 60. Geburstag, [red. z Katją Bernhardt, współautorstwo], Berlin: Lukas Verlag, 2006, ss. 262.

Centropa, [Nationalism and Democracy, red. gościnny, współautor], Vol. 8, No. 1, January 2008.

Perspektywy wspótczesnej historii sztuki. Antologia przekładów „Artium Quaestiones”, [współredakcja z: M. Bryl, P. Juszkiewicz, W. Suchocki], Poznań: Wydawnictwo Naukowe UAM, 2009, ss. 1088. 
From Museum Critique to the Critical Museum, [red. z Katarzyną Murawską-Muthesius, współautor], „Ashgate”, 2015, ss. 272.

„Czas Kultury”, 3 (186)/2015, numer specjalny „Kryzys uniwersytetu” [redaktor gościnny].

\section{ARTYKUŁY}

Przeciwko instytucjom, „Sztuka”, Warszawa, 1976, nr 6, ss. 52-56.

Witkacy jako Portrecista, „Sztuka”, Warszawa, 1978, nr 2, ss. 28-30.

Portrety $i$ społeczeństwo. O firmie portretowej S.I. Witkiewicz, (w:) Problemy interpretacji dzieła sztuki i jego funkcji społecznych, red. K. Kalinowski, Poznań: Wydawnictwo Naukowe UAM, 1980, ss. 154-168.

Dialektyka kryzysu, „Miesięcznik Literacki”, Warszawa, 1981, nr 1, ss. 65-70.

Witkacy i paradygmat awangardy, (w:) Sztuka dwudziestolecia międzywojennego, Warszawa: PWN, 1982, ss. 113-125.

Sztuka a okres miniony, „Miesięcznik Literacki”, Warszawa, 1982, No 9, ss. 50-56; por: Bez zgody, „Tygodnik Powszechny”, 1982, nr 48, s. 4.

Retoryka banknotu, „Artium Quaestiones”, II, Poznań: Wydawnictwo Naukowe UAM, 1983, ss. 131-143.

Kosmos i forma, „Biuletyn Historii Sztuki”, Instytut Sztuki PAN, Warszawa 1985, nr 3-4, ss. 319-325; angielskojęzyczna wersja: Cosmos and Form, Polish Art Studies, Instytut Sztuki PAN, vol. IX, Wrocław 1988, ss. 211-222.

Autonomia, symbol, utopia, „Artium Quaestiones”, III, Poznań: Wydawnictwo Naukowe UAM, 1986, ss. 109-129.

Filozofia gestu, (w:) Sztuka Polska po 1945, Warszawa: PWN, 1987, ss. 243-253.

Oblicze artystycznego Poznania, „Kronika Miasta Poznania”, LV, Poznań 1987, nr 1, ss. 19-30.

On the Ethos of the Polish Artist, „Art Monthly”, No 103, London, February 1987, ss. 11-15.

Autokomentarz destrukcyjny, (w:) Autokomentarz artysty, „Zeszyty Naukowe Akademii Sztuk Pięknych”, nr 2/20, Warszawa 1987, ss. 114128; tekst drukowany też częściowo w: „Res Publica”, Warszawa 1988, nr 10, ss. 53-58, oraz we Francji jako: L'Autocommentaire destructeur, „Ligeia”, No 3-4, Paris 1989, ss. 129-134. 
Kryzys awangardy czy kryzys sztuki, (w:) Kryzysy w sztuce, Warszawa: PWN, 1988, ss. 167-176; wcześniej artykuł publikowany w: „Przegląd Powszechny", Warszawa 1987, nr 5, ss. 196-210.

La conception plastique du theatre chez Witkiewicz, „Ligeia”, No 2, Paris 1988, ss. 60-71.

Art in the Crucible of History, „The Polish Review”, vol. XXXIII, New York 1988, No 2, pp. 123-142.

Awangarda uwiktana, „Szkice”, nr 9, Warszawa 1989, ss. 19-26.

The Dialectics of Destiny, „Artium Quaestiones”, V, Poznań: Wydawnictwo Naukowe UAM, 1991, ss. 85-98; w języku polskim jako: Dialektyka przeznaczenia, „Skrypt”, UAM, nr 5, 1992, ss. 14-26.

Wielkie kwestie i martwa natura. Sztuka lat trzydziestych, Warszawa: Stowarzyszenie Historyków Sztuki, 1991, ss. 5-16.

Awangarda $i$ historia. Sztuka i Historia, Warszawa: PWN, 1992, ss. 325-334; wcześniej tekst opublikowany w: Sprawozdania Komisji Historii Sztuki Poznańskiego Towarzystwa Przyjaciół Nauk, vol. 106, Poznań 1989, ss. 50-59; w jęz. francuskim: Avant-garde et histoire, „Ligeia”, No 11-12, Paris, Decembre 1992, ss. 5-11.

Moralność Inc., „Czas Kultury”, nr 3 (marzec-kwiecień) 1992, ss. 3439; por. list do redakcji: Moralność Inc., Drodzy Koledzy, „Czas Kultury”, nr 4 (maj-czerwiec) 1992, ss. 78-79.

W poszukiwaniu alternatywy; odpowiadajac Beuysowi, „Obieg”, 1992, $\mathrm{nr}$ 4-5, ss. 9-14; wersja skrócona oraz $\mathrm{w}$ języku angielskim jako: In Search of an Alternative, The Wealth of Nations, ed. C. Lauf, Gent, Imschoot uigevers, 1993, ss. 55-64; wersja rozszerzona: In Search of an Alternative, Actes del III Congreso „Cultura Europea”, Universidad de Navarra, Aranzadi Editorial: Pamplona 1966, ss. 371-376; przedruk: W poszukiwaniu alternatywy - odpowiadajac Beuysowi / In Search for an Alternative - a Response to Beuys, Aneta Szylak, Jan Sowa (red.) Na okragto: 1989-2009/ Over and Over Again: 1989-2009, Wrocław: Korporacja Ha!art/ BWA - Galeria Sztuki Współczesnej, 2009, ss. 131-144.

Przedmiot jako kultura. Duchamp i Ameryka śladami Baudrillarda, „Format”, Wrocław 1993, nr 8-9, ss. 3-5, 112.

Art and Independence: Polish Art in the 1920s, „Artium Quaestiones”, VI, Poznań: Wydawnictwo Naukowe UAM, 1993, ss. 31-37.

Ameryka-Europa, „Kresy”, nr 16, Lublin, jesień 1993, ss. 232-238.

Z bluźnierczej historii sztuki, (w:) Andres Serano. Prace $z$ lat 19861992, Warszawa: Centrum Sztuki Współczesnej, 1994, ss. 7-18; wersja 
angielskojęzyczna: From the Blasphemous History of Art, (w:) Andres Serrano. Works from 1986-1992, Warsaw, Center for Contemporary Art, 1994, pp. 7-18; także: Iz bogokletne zgodovine umetnostil From the Blasphemous History of Art, (w:) Andres Serrano, Ljubljana: Moderna Galerija, 1994.

Listy $z$ Nowego Jorku, cz.: I, II, III, IV, „Nowy Nurt”, 1994, nr 9 (s. 12), 10 (ss. 13-14), 12 (s. 12), 13 (ss. 13-14).

Post-modernism and Post-totalitarianism. The Poland Case of the 1970s, ARS, No 2-3, 1993, Bratislava: Slovak Academic Press, 1994, ss. 231-242; wersja szersza: Postmodernizm i posttotalitaryzm, „Magazyn Sztuki”, nr 4, 1994, ss. 56-73 oraz w wydaniach magazynu z wersją angielskojęzyczną Post-Modernism and Post-Totalitarianism, ss. 213-222.

Kunst und Geschichte: über die Grenzen der Polnischen Gegenwartskunst, (w:) Der Riss im Raum. Positionen der Kunst seit 1945 in Deutschland, Polen, der Slovakei und Tschechien, Guardini Stiftung, Verlag der Kunst, Berlin 1994, ss. 58-64; wersja polskojęzyczna: Artysta i historia. W strone granicy wspótczesnej sztuki polskiej, (w:) Rysa w przestrzeni. Sztuka po 1945 roku w Czechach, Niemczech, Polsce $i$ Stowacji, Warszawa: Galeria Sztuki Współczesnej Zachęta, 1995, ss. 27-32.

Awangarda między estetyka i polityka. Konstruktywizm w opinii publicznej, 1921-1934, (w:) Władysław Strzemiński, 1893-1952. Materiały z Sesji (1993), Biblioteka Muzeum Sztuki, Łódź 1994, ss. 108-124; wersja angielskojęzyczna jako: The Avant-Garde between Aesthetic and Politics. Constructivism as Seen by Public, 1921-1934, (w:) Władysław Strzeminski, 1893-1952. Materials of the Conference, Łódź: Muzeum Sztuki, 1995, ss. 108-122.

Ciało artysty, (w:) Jerzy Bereś: Zwidy, Wyrocznie, Ottarze, Wyzwania, Poznań: Muzeum Narodowe, 1995, ss. 33-39; wersja angielskojęzyczna: The Artist's Body, ss. 40-46; oraz (w:) Art and National Identity in Poland and England. Papers delivered at the University of London History of Art Conference, ed. A. Kwilecka, F. Ames-Lewis, London: Dept. of History of Art, Birkbeck College, 1996, ss. 135-148; nieco zmieniona wersja w języku słowackim: Telo umelca. Jerzy Bereś, (w:) Rezonancie '98, red. Z. Bartońova, Bratislava: AICA, Slovenska Sekcia, 2001, ss. 87-100.

Henryk Stażewski - modernista?, „Odra”, 1995, nr 5, ss. 62-68.

Ambivalenses Kunster/ Man among Ambivalences, Terskel/Threshold, No. 15, September 1995, Museet for Samtidskunst, Oslo 1995, ss. 7-23; polskie wydanie: Człowiek wśród ambiwalencji/ Man among Ambivalences, „Magazyn Sztuki”, nr 6-7, 1995, ss. 134-151; wydanie wę- 
gierskie: Ember az ambivalenciák között. Jarosław Kozłowski, Budapest: Balkon, 1997, No. 1-2, ss. 42-44.

The Old Attitude and the New Faith, (w:) Beyond Belief: Contemporary Art from East Central Europe, Museum of Contemporary Art, Chicago 1995, ss. 34-45; rozszerzona wersja: Poza stara i nowa wiara / Beyond the Old and New Belief, „Magazyn Sztuki”, nr 10, 1996, ss. 144-176.

Rosja i Ameryka; awangarda i modernizm, „Artium Quaestiones”, VII, Poznań 1995, ss. 153-170.

Die Kunst im Spiegel der Geschichte, (w:) Der Riss im Raum. Dokumentation, Gaurdini Stiftung, Berlin 1995, ss. 25-37; wersja angielskojęzyczna: Art on the Mirror Stage, (w:) Crossroads in Central Europe/ Carrefours en Europe centrale: Ideas, Themen, Methods and Problems of Contemporary Art and Art Criticism/ Des idée, des méthodes et des problémes de l'art et du critique d'art contemporains, Budapest: Association of Hungarian Creative Artists/Association Nationale des Artistes Créatifs Hongrois, 1996, ss. 62-71.

Modernismus und sozialistische Kultur im Polen der späten 50 Jahre, (w:) Die Depots der Kunst, Dokumentationszentrum Kunst der DDR, Beeskow [1997] ss. 40-46.

Art versus History; History versus Art, (w:) Art from Poland, 19451996, Warsaw: Zachęta, 1997, ss. 209-257.

Post-War Central Europe: Art, History, and Geography, „Krasnogruda”, No. 8, Sejny (Poland) - Stockholm 1998, ss. 27-34; mniejsza wersja: Iskustwo w kontiekst, „Kultura”, [Sofia], No. 32, 1998, ss. 9, 12.

W strone nowej geografii artystycznej/ Towards a New Geography of Art, „Magazyn Sztuki”, nr 19 (3/98), 1998, ss. 76-99; mniejsza wersja: Framing Central Europe, Moscow „Art Magazine”, No. 22, 1998, ss. 5566, oraz: 'Rámováni' středni Evropy, „Umélec”, Praha, 1999, No. 4, ss. 3435.

Mońko umetnikovo telo. Nacionalna identiteta proti politiki identitete / Male Artis's Body. National Identity vs. Identity Politics, w: „M'Ars”, Ljubjana: Moderne Galerije, No. 1-2, 1998, ss. 14-30; wersja internetowa: Male Artist's Body: National Identity vs. Identity Politics, (w:) Art Margins. Contemporary Central and Eastern European Visual Culture, www.gss.ucsb.edu/artmargins [5 December, 1999]; przedruk: Primary Documents. A Sourcebook for Eastern and Central European Art since 1950s, eds L. Hoptman \& T. Pospiszyl, New York/ Cambridge MA: MOMA/ The MIT Press, 2002, ss. 225-234 oraz Mail Artist's Body: National Identity vs. Identity Politics, Bojana Pejić (ed.) Gender Check: 
A Reader. Art and Theory on Eastern Europe, Köln: Walther König, 2010, ss. 127-137; szersza wersja w języku polskim: Sztuka męskiego ciała: tożsamość narodowa i polityka tożsamości, „Format”, nr 31-32, 1999, s. $15-20$.

Między koloryzmem a modernizmem. W stronę estetyki recepcji malarstwa Piotra Potworowskiego [Between Colorism and Modernism. Towards the Reception Aesthetics of Piotr Potworowski Painting], (w:) Piotr Potworowski, 1898-1962, Warszawa: Galeria Sztuki Współczesnej „Zachęta", 1998, ss. 45-54.

Between History and Geography: in Search for the Identity of Central Europe, (w:) Culture of the Time of Transformation. II International Congress: The Cultural Identity of the Central-Eastern Europe, Poznań: WiS Publishers, 1999, ss. 39-45.

The Grey Zone of Europe, (w:) After the Wall. Art and Culture in Post-Communist Europe, Stockholm: Moderna Museet, 1999, ss. 35-41; Przedruk: The Grey Zone of Europe, red. Phoebe Adler, Duncan McCorquodale Contemporary Art in Eastern Europe, London: Black Dog Publishing, 2010, ss. 199-206. Krótsza wersja w języku polskim: Szara strefa Europy, „Format”, nr 33/34, Wrocław 2000, ss. 54-60; wersja w języku ukraińskim: Cira zona Efropy, Suĉasnost, Kijiv, No. 1/ 2002, 140-149.

Obraz po wielkiej wojnie, (w:) Sztuka w okresie PRL-u, red. T. Gryglewicz, A. Szczerski, Kraków: Instytut Historii Sztuki UJ, 1999, s. 13-25.

Sztuka w czasie końca utopii, „Biuletyn Historii Sztuki”, nr 3-4, 1999, s. 267-282.

Sztuka wedtug polityki/ Art after Politics, (w:) Negocjatorzy sztuki wobec rzeczywistości / Negotiators of Art facing Reality, Gdańsk: Centrum Sztuki „Łaźnia”, 2000, ss. 20-34, 139-147; skrócona wersja ukraińska: Mistiectvo zgidno z politikoj, „Kritika”, No. 11 (37), Kijiv listopad 2000, s. $16-22$.

L'autre Europe, (w:) L'autre moitié de l'Europe, red. D. Abadie, Paris: Gelerie National du Jeu de Paume/ Réunion des Musées Nationaux, 2000, s. 19-32.

Totalitarianism and Modernism: The 'Thaw' and Informel Painting in Central Europe, 1955-1965, „Artium Quaestiones”, Vol. X, Poznań 2000, s. 119-174; wersja znacznie skrócona: Modernism in Central Europe in the late 1950s", Art Margins. Contemporary Central and Eastern European Visual Culture, www.artmargins.com.

Modernism and Socialist Culture: Polish Art in the late 1950s, (w:) Style and Socialism. Modernity and Material Culture in Post-War 
Eastern Europe, red. S.E. Reid, D. Crowley, Oxford \& New York: Berg Publishers, 2000, s. 133-147.

Modernism and Totalitarianism II. Myths of Geometry: NeoConstructivism in Central Europe, 1948-1970, „Artium Quaestiones”, XI, Poznań 2000, s. 101-154.

The Geography of Central / East European Art", Borders in Art. Revisiting Kunstgeographie, ed. K. Murawska-Muthesius, University of East Anglia, Norwich/ Institute of Art, Warsaw 2000, s. 43-50; The Geography of Central and East European Art, On Cultural Influence. Collected Papers from Apexart International Conferences, eds Steven Rand, Heather Kouris, New York: Apexart, 2006, ss. 97-105.

Między totalitaryzmem i demokracja. Pomnik 'Poznańskiego Czerwca 1956’, „Kronika Miasta Poznania”, Pomniki, Poznań 2001, nr 2, 195-210; tekst w języku niemieckim: Zwischen Totalitarismus und Demokratie: Das Denkmal zum Posener Juni 1956, (w:) Denkmäler in Kiel und Posen. Parallelen und Kontraste, Kiel: Verlag Ludvig, 2002, s. 250-264.

Surrealistyczne interregnum, Mistrzowi, red. T. Gryglewicz, Kraków: Instytut Historii Sztuki, Uniwersytet Jagielloński, 2001, s. 297-326.

Krytyka obrazu. W stronę neoawangardy Europy Środkowej lat sześćdziesiatych, „Artium Quaestiones”, XII, 2001, s. 161-238.

„Framing of the Central Europe”, 2000+ Art East Collection. The Art of Eastern Europe. A Selection of Works for the International and National Collection of Moderna Galerija, Ljubljana, Innsbruck: Orangerie Congress/ Wien-Bozen: Folio Verlag, 2001, 15-22; w Rumunii: Framing of the Central Europe, La Biennale di Venezia. 51 Esposizione Internazionale d'Arte. Romanian Pavilion/ Pavilionul Romaniei, 2005, ss. 514-550. Skrócona wersja po czesku: Rámováni Středni Evropy, Jiři Ńevĉik et. al. Ceské uméni, 1980-2010. Texty a dokumenty, Praha: AVU, 2011, ss. 321325.

Obraza uczuć. Odbiór sztuki krytycznej w Polsce, „Res Publica Nowa”, Warszawa, nr 3/2002, s. 40-44.

Modernity and Nationalism. Avant-Garde and Polish Independence, 1912-1922, (w:) Central European Avant-Gardes: Exchange and Transformation, 1910-1930, Los Angeles/ Cambridge MA: Los Angeles County Museum of Art/ The MIT Press, 2002, ss. 312-326.

[wybór i komentarze części poświęconej polskiej sztuce] Between Worlds. A Sourcebook of Central European Avant-Gardes, 1910-1930, ed. T.O. Benson \& E. Forgacs, Los Angeles CA./ Cambridge MA.: Los Angeles County Museum of Art/ The MIT Press, 2002. 
[współautorstwo] East Art Map: a (Re)construction of the History of Art in Eastern Europe, „New Moment”, No. 20, Ljubljana 2002; przedruk: Poland, East Art Map. Contemporary Art and Eastern Europe, IRWIN (ed.), London: Afterall Book, 2006, pp. 245-251.

$O$ „sztuce dziš”, a więc „tu i teraz”, Sztuka dzisiaj. Materiaty $z$ sesji Stowarzyszenia Historyków Sztuki (Warszawa, listopad 2001), red. M. Poprzęcka, Warszawa: Stowarzyszenie Historyków Sztuki, 2002, ss. 17-26.

Nad mapa neoawangardy Europy Środkowej lat siedemdziesiatych XX wieku, „Artium Quaestiones”, XIII, Poznań 2002, ss. 125-228.

Ein neue Kunst - ein neuer Staat, Der neue Staat. Polinische Kunst, 1918-1939, zwischen Experiment und Repräsentation, eds R. Schuler \& G. Gawlik, Wien: Leopold Museum/Hatje Cantz Verlag, 2003, ss. 51-68.

The Avant-Garde Institutionalised? The 1932 City of Łódź Art Prize Awarded to Władysław Strzemiński, "Uměni/ Art. Ĉasopis Ústavu dějin uměni Akademie věd Ceské republiky/Journal of the Institute for Art History of the Academy of Sciences of the Czech Republic", 2003, No. 3, ss. 211-218.

Agorafobia po komunizmie/ Postkommunistische Agoraphobia, Publiczna przestrzeń dla sztuki?/ Öffentlisher Raum für Kusnt?, red. M.A. Potocka, Kraków/ Wien: Bunkier Sztuki, Inter Esse/ Triton Verlag, 2003, ss. 179-237. W języku angielskim z czeskim streszczeniem: Agoraphobia after Communism, „Uměni/ Art. Ĉasopis Ústavu dějin uměni Akademie věd Ĉeské republiky/ Journal of the Institute for Art History of the Academy of Sciences of the Czech Republic", 2004, No. 1, ss. 52-60; wersja szersza: Visual Art Policy in Poland: Democracy, Populism and Censorship, Populism. The Reader, New York/ Frankurt am Main: Lukac \& Sternberg/ Frankfurter Kunstverein, 2005, ss. 187-193; w Rumunii: Cenzura crucificarii: arta, politica si democratie in Polonia/ To Censor the Crucifixion, and Democracy in Poland, „Idea. Arta+Societate/ Art+ Society", No. 20, 2005, ss. 148-155. Po ukraińsku: Aforabia pislia komunizmy, Kijewskaja rys, Kiew, No. 7-8, 2009, ss. 181-199.

Ciało $i$ tożsamość. Sztuka ciała w Europie Środkowej, „Artium Quaestiones", Poznań: Wydawnictwo Naukowe UAM, 2003, ss. 201-256.

Central Europe in the Face of Unification, Who if not we should at least try to imagine the future of all this, red. Maria Hlavajova and Jill Winder, Amsterdam: Artimo, 2004, ss. 271-281 oraz www.artmargins.com.

Auschwitz versus Auschwitz, „Pro Memoria”, No. 20, (styczeń 2004), ss. 15-23. W języku angielskim: Auschwitz vs. Auschwitz, Zerstörer des Schweigens. Formen künstlerischer Erinnerung an die nationalsozialisti- 
sche Rassen- und Vernichtungspolitik in Osteuropa, Frank Grüner, Urs Heftrich, Hans-Dietrich Löwe (hrsg.), Köln: Böhlau, 2006, ss. 515-530.

Geography of Changes - Changes of Geography?, Anxiety of Influence. Bachalors, Brides, and a Family Romance, red. Adam Budak, Bern: Stadtgalerie, 2004, ss. 84-97.

Od nacjonalizacji do socjalizacji polskiego modernizmu, 1913-1950, „Artium Quaestiones”, XV, Poznań: Wydawnictwo Naukowe UAM, 2004, ss. 97-138.

Polska sztuka między totalitaryzmem a demokracja, WarszawaMoskwa, Moskwa-Warszawa, 1900-2000, red. Maria Poprzęcka, Warszawa: Narodowa Galeria Sztuki „Zachęta”, 2004, ss. 87-98; wersja rosyjska: Polskoje iskustvo miezdu totalitarizmom i diemokracjej, MoskvaWarszawa Warszawa-Moskva, 1900-2000, Moskva: Gosudarstviennaja Trietiakovskaja Galerja, 2005, ss. 98-106; przedruk: Polish Art between Totalitarianism and Democracy/ Umetnost u Poljskoj - izmedu totalitarizma i demokratije/Polska sztuka między totalitaryzmem i demokracja, (w:) Piotr Nowicki (red.), Behind the Iron Curtain. Official and Independent Art in the Soviet Union and Poland, 1945-1989/ Iza Gvozdene. Zvanićna i nezavisna umetnost u Sovjetskom Savezu i Poljkos, 1945-1989/ Za żelazna kurtyna. Sztuka oficjalna i niezależna w Związku Radzieckim i Polsce, 1945-1989, Warsaw: Polish Modern Art Foundation, 2010 [Beograd], ss. 63-76 (English), ss. 60-75 (jęz. serbski), ss. 64-78 (jęz. polski).

Between Place and Time: a Critical Geography of 'New' Central Europe, (w:) Time and Place. The Geohistory of Art, red. Thomas DaCosta Kaufmann and Elizabeth Pilliod, Hants: Ashgate, 2005, ss. 153-171.

Nagroda Rembrandta, (w:) Tadeusz Kantor. Interior imaginacji, red. Jarosław Suchan i Marek Świca, Warszawa/ Kraków: Narodowa Galeria Sztuki Zachęta/ Ośrodek dokumentacji sztuki Tadeusza Kantora Cricoteka, 2005, ss. 33-45; wersja angielska: The Rembrandt Prize, Tadeusz Kantor. Interior of Imagination, red. Jarosław Suchan and Marek Świca, Warszawa/ Kraków: National Gallery of Art Zachęta/ Center of the Documentation of the Art of Tadeusz Kantor Cricoteka, 2005, ss. 33-45.

O końcu Europy Środkowej i praktykach kuratorskich, (w:) Mowa i moc obrazów. Prace dedykowane Marii Poprzęckiej, Warszawa: Wydawnictwo Uniwersytetu Warszawskiego, 2005, ss. 398-404.

Art Criticism in Defence of Regionalisation in post-1989 Eastern Europe, (w:) The Regionalisation of Art Criticism: Its Possibility and Interventions in Space, Taiwan: AICA, 2005, ss. 13-21.

Von der Neoavantgarde zur kritishes Kunst - vom weichen Socialismus zur unvollkommenen Democratie/ From Neo-Avant-Garde to Criti- 
cal Art - From Soft Socialism to Imperfect Democracy, Kontakt... aus der Sammlung der Erste Bank-Gruppe/ Kontakt... works from the collection of Erste Bank Group, Wien: Museum Moderner Kunst Stiftung Ludwig, 2006, ss. 62-73.

Bridging the Past and Present, red. Katrin Klingan \& Ines Kappert, Leap into the City, Cologne: DuMont Literatur und Kunst Verlag, 2006, ss. 358-371.

Mapping the Legacy of the Political Change of 1956 in East European Art, „Third Text”, London: Routledge, Vol. 20, Issue, 2, March, 2006, ss. 211-221.

Drang nach Westen. The Visual Rhetoric of Polish „Western Politics”, in the 1930s, (w:) Visuelle Erinnerungskulturen und Geschchtskonstruktionen in Deutschland und Polen 1800 bis 1939, Robert Born, Adam S. Labuda, Beate Störtkuhl (hrsg), Warszawa: Instytut Sztuki Polskiej Akademii Nauk, 2006, pp. 465-480.

On Two Voices of Art History, (w:) Grenzen überwindend. Festschrift für Adam S. Labuda zum 60. Geburstag (współred. z Katją Bernhardt), Berlin: Lukas Verlag, 2006, ss. 42-56, także: w: Modernism and Central-and East-European Art \& Culture, Osaka: Osaka University, 2007, ss. 319-337; W języku polskim: $O$ dwóch głosach historii sztuki, „Artium Quaestiones", XVII, 2006, ss. 195-214.

„Pazurami i dziobem” $w$ obronie demokracji, www.obieg.pl/artmix/ar tmix15_01.php

Biopolityka i demokracja, (w:) Krzysztof Wodiczko. Doktor honoris causa Akademii Sztuk Pięknych w Poznaniu, Poznań: ASP, 2007, ss. 1326. Przedruk: Biopolityka i demokracja, „Czas Kultury”, nr 4-5, 2007, ss. $189-201$.

Nova Demokracja - nova cenzura, (w:) Vizualniat Obraz, Sofia: New Bulgarian University, 2007, ss. 13-25.

From the Politics of Autonomy to the Autonomy of Politics, Meno istorija ir kritika, „Art History \& Criticism” [Art and Politics: Case-Studies from Eastern Europe], No. 3, Vytautas Magnus University, Kaunas 2007, pp. 18-24; znacznie zmieniona wersja w jęz. polskim: Śladami Louisa Althusera. O polityce autonomii $i$ autonomii polityki $w$ sztuce Europy Wschodniej, www.obieg.pl/artmix/artmix13_01.php.

Beyond Democracy, „Centropa, Nationalism and Democracy”, Vol. 8, No. 1, January 2008, ss. 5-15.

Czy (wciaż) istnieje Europa Środkowa i czy (jeszcze) ma coś do powiedzenia/ Does Central Europe (still) Exist, and Does it (still) Have Someth- 
ing Important to Say?, Mediations Biennale, Poznań: Centrum Kultury „Zamek”, 2008, ss. 28-55.

Jeneseits der Demokratie. Zum Verhältnis von Kunst, Staat und Kirche in Polen, „Springerin. Hefte für Gegenwartskunst”, [My Religion], Vol. XIV, 2008, 4, ss. 42-47.

On the Spatial Turn, or Horizontal Art History, „Umeni/ Art”, No. 5, 2008, ss. 378-383. Krótsze wersje: Towards Horizontal Art History, (w:) Crossing Cultures. Conflict. Migration, and Convergence, Jaynie Anderson (ed.) Melbourne: The Miegunyah Press, 2009, ss. 82-85.

Towards a Horizontal History of the European Avant-Garde, (w:) Europa! Europa? The Avant-Garde, Modernism and the Fate of a Continent, Sascha Bru et al. (eds.), Berlin: De Gruyter, 2009, ss. 49-58. Polska pełna wersja: O horyzontalnej historii sztuki, „Artium Quaestiones”, XX, Poznań: Wydawnictwo Naukowe UAM, 2009, ss. 59-73. Wersja krótsza: On the Spatial Turn, Christine Macel et al., Promises of the Past. A Discontinuous History of Art in Former Eastern Europe, Paris: Centre Pompidou, 2010, ss. 212-215 [także w edycji francuskojęzycznej]. Inne wersja francuskojęzyczna: Du tournant spatial ou une histoire horizontale de l'art, Kantuta Quirós, Aliocha Imhoff (dir.) „Géo-esthétique”, Dijon: Édition B42, 2014, ss. 123-131.

How to Write a History of Central-East European Art?, „Third Text”, (London: Routledge) Vol. 23, No. 96, January 2009, ss. 5-14.

Artysta $w$ Auschwitz. O (nie)banalności sztuki, (w:) Zagłada: wspótczesne problemy rozumienia i przedstawiania, Przemysław Czapliński, Ewa Domańska (red.), Poznań: Poznańskie Studia Polonistyczne, 2009, ss. 291-307.

Modernism after the end of Modern Art / Modernism parast moods kunsti loopu, (w:) Different Modernisms, Different Avant-Gardes. Problems in Central and Eastern European Art after World War II/ Erinevad Modernismid, Erinevad Avangardid. Kesk-ja Ida-Euroopa Kunstiprobleemid Parast Teist Maailmosoda, Sirje Helme (red.), Tallinn: Eesti Kunstimuuseum KUMU, 2009, ss. 208-233.

Zbigniew Libera: anarchia i krytyka, (w:) Zbigniew Libera. Prace z lat 1982-2008, Dorota Monkiewicz (red.), Warszawa: Zachęta - Narodowa Galeria Sztuki, ss. 8-18. Wersja angielskojęzyczna: Zbigniew Libera: Anarchy and Criticism, (w:) Zbigniew Libera. Works from 1982-2008, Dorota Monkiewicz (ed.), Warsaw: Zachęta - National Gallery of Art, pp. 8-18.

Gender after the Wall, (w:) Gender Check. Feminity and Masculinity in the Art of Eastern Europe, Bojana Pejić (ed.), Wien/ Cologne: Museum 
Moderner Kunst Stiftung Ludwig/Verlag der Buchhandlung Walter König, 2009, ss. 236-240. Wersja w języku polskim: Gender po murze, (w:) Pteć? Sprawdzam! Kobiecość $i$ męskość w sztuce Europy Wschodniej, Warszawa: Zachęta Narodowa Galeria Sztuki, 2010, ss. 75-79.

New Museums in East-Central Europe. Between Traumaphobia and Traumaphilia/ Traumatofilia i traumatofobia. Nowe Muzea w Nowej Europie, (w:) 1968/1989: Political Upheaval and Artistic Change/ Momenty zwrotne w polityce I sztuce, Clair Bishop, Marta Dziewanska red., Warszawa: Muzeum Sztuki Nowoczesnej, 2009, ss. 148-166, 418-437. Krótsza wersja: New Museums / New Europe, Maria Orińková (ed.), Curating „Eastern Europe” and Beyond. Art Histories trough the Exhibition, Frankfurt am Main/ Bratislava: Peter Lang/ Veda - Slovak Academy of Science, 2013, ss. 91-99.

Art after Politics (w języku chińskim) Fudan Wenshi Jiangtang, Shanghai: Fudan University, 2010, ss. 195-212.

„Francuskie teorie”, amerykańska mediacja, polska redakcja. Pro domo sua i/lub humanistyka po dekonstrukcji, French Theory w Polsce, Ewa Domańska, Mirosław Loba (red.), Poznań: Wydawnictwo Poznańskie, 2010, ss. 105-116.

O dymisji znaczonego, (w:) Bożena Czubak (red.) Cudzystowy. Jarostaw Kozłowski, Warszawa: Profile, ss. 281-289. W języku angielskim: On the Dismissal of the Signified, Bożena Czubak (red.), Quotation Marks. Jarosław Kozłowski, Warszawa: Profile, 2010, pp. 281-289.

Historyk sztuki między akademia i muzeum, (w:) Historia sztuki dzisiaj. Materiaty LVIII Ogólnopolskiej Sesji Naukowej Stowarzyszenia Historyków Sztuki, Janusz Pazder et al. (red), Warszawa: Stowarzyszenie Historyków Sztuki, 2010, ss. 213-221.

A General and Universal Concept of Resistance, (in:) Performing History, Romanian Pavilion at the $5^{\text {th }}$ International Art Exhibition, La Biennale di Venezia 2011, ss. 90-93.

Museum: From the Critique of Institution to a Critical Institution, Tone Hansen (ed.), (Re)Staging the Art Museum, Høvikodden: Henie Onstad Art Center, 2011, ss. 77-90.

On (former) Eastern Europe: Discussing the Post-Communist Condition in Art, (in:) Iwona Szmelter (ed.), Innovative Approaches to the Complex Care of Contemporary Art, Warsaw/ London: Academy of Fine Arts/ Archetype Publications Ltd., 2012, ss. 74-82.

From Communist to Post-Communist Condition, (in:) Ieva Astahovska (red.), Recuperating the Invisible Past, Riga: The Latvian Center for Contemporary Art, 2012, ss. 16-27. 
From the International to the Cosmopolitan, (in:) Christian Höller (ed.), L'Internationale. Post-War Avant-Gardes between 1957-1986, Zürich: JRP|Ringier, 2012, ss. 302-310.

Writing on Art after 1989, (in:) Hans Belting, Andrea Buddensieg, Peter Weibel (eds.), The Global Contemporary and the Rise of New Art Worlds, Karlsruhe/ Cambridge MA: ZKM| Center for Art and Media/ The MIT Press, 2013, ss. 202-207; wersja internetowa: http://www.globalart museum.de/site/guest_author; w języku niemieckim: Schreiben über Kunst nach 1989, Kunstforum International, Bd. 220, März-April 2013, ss. 70-85.

Od globalnej do alterglobalistycznej historii sztuki, „Teksty Drugie”, IBL-PAN, Warszawa, nr 1-2, 2013, ss. 269-291; drugie wydanie w: Maria Poprzęcka (red.), Historia sztuki wobec globalizacji, Warszawa: Stowarzyszenie Historyków Sztuki, 2013, ss. 7-30.

Critical Objects. The De-Musealization of Art?, (in:) G. Urlich Grossmann, Petra Krutisch (eds.), The Challenge of the Object, Nürnberg: Germanisches Nationalmuseum, 2013, Part 1, ss. 406-410.

Avant-Garde in Post-Communist Central Europe, (in:) Per Bäckström and Benedikt Hjartarson (eds.), Decentring the Avant-Garde, Amsterdam/ New York: Rodopi, 2014, ss. 117-141.

East European Art Peripheries Facing Post-Colonial Theory http://non site.org/article/east-european-art-peripheries-facing-post-colonial-theory, No. 12, 2014. W języku słowackim: Východoeurópske umelecké periférie zoĉi-voĉi postkoloniálnym teóriám, Jazdek. Print Nástenky o Suĉasnom Výtvarnom Diani, Bratislava, 2014, No. 1, ss. 1, 8-12. Wersja rozszerzona w języku polskim: Wschodnioeuropejskie peryferia artystyczne $w$ obliczu teorii postkolonialnej, „Konteksty”, 2014/ LXVIII, No. 2 (305), ss. 262-272.

Muzeum naukowe, „Muzealnictwo”, 2014, nr 55, ss. 14-18.

Globalny NETwork. W strone porównawczej historii sztuki, „Artium Quaestiones", XXV, Poznań: Wydawnictwo Naukowe UAM, 2014, ss. 139175.

Peryferie wszystkich części świata łaczcie się, „Rocznik Sztuki Śląskiej”, 2014, nr XXIII, ss. 277-285.

Krzysztof Wodiczko i światowa politeja, (w:) Krzysztof Wodiczko and the Global Politeia, Bożena Czubak (red.), Krzysztof Wodiczko. Na rzecz domeny publicznej/ On Behalf of the Public Domain, kat. wyst., Muzeum Sztuki w Łodzi, 2015, s. 49-61.

The Global NETwork: An Approach to Comperative Art History, (w:) Circulations in the Global History of Art, Thomas DaCosta Kaufmann, Catherine Dossin, Béatrice Joyeux-Prunel (eds.), Ashgate, 2015, s. 149-165. 
Making the National Museum Critical, (w:) From Museum Critique to the Critical Museum, red. Katarzyna Murawska-Muthesius, Piotr Piotrowski, „Ashgate” 2015, s. 137-146.

Pop Art and Gread Art. The Eastern Europe viewpoint, Baltic Worlds, "October" 2015, Vol. VIII: 3-4, ss. 10.

Andrzej Matuszewski i Galeria odNOWA jeszcze raz, (w:) Andrzej Matuszewski, książka wyd. przez Fundację 9/11 Art Space, Poznań 2015.

Why have there no been great Pop Art curatorial projects in Eastern Europe in the 1960s?, Öhrner, Annika (ed.), Art in Transfer in the Era of Pop, Södertörn Studies in Art History and Aesthetics [w przygotowaniu] (2016).

Gender Un-balanced: KwieKulik and the Others, Arnoux, Mathilde (ed.), OwnReality-series, on www.own-reality.org [w przygotowaniu].

RECENZJE, KOMUNIKATY, DYSKUSJE ETC.

Henri Chopin w Galerii Akumulatory 2, „Nurt”, Poznań 1975, nr 8, ss. 34-35.

Sztuka elitarna, (w:) Konfrontacje Studentów Szkót artystycznych, Szczawno Zdrój, Warszawa 1977, ss. 47-55.

Prywatna czy publiczna?, „Kultura”, Warszawa 1977, nr 39.

Akumulatory 2, „Literatura”, Warszawa 1978, nr 20, s. 13.

Potrzebna czy nie?, „Kurier Festiwalowy”, Warszawa 1978, nr 4, ss. 1-2.

Foksal: wahania awangardy, „Kultura”, Warszawa 1979, nr 31.

O książe A. Turowskiego „W kręgu konstruktywizmu” [głos w dyskusji], „Sztuka”, Warszawa 1980, nr 4, ss. 1-10.

Demoniczny fotograf, „Teksty”, Instytut Badań Literackich PAN, Warszawa, 1980, nr 2, ss. 171-178.

Utopie rewolucji, „Miesięcznik Literacki”, Warszawa, 1980, nr 9, ss. 138-141; angielskojęzyczna wersja: Utopias of the Revolution, (w:) Polish Art Studies, Instytut Sztuki PAN, vol. III, Wrocław 1982, ss. 275-279.

La Firme de Portaits, (w:) Presences polonaises, Centre Georges Pompidou, Paris, 1983, ss. 74-81.

Documenta 8, „Szkice”, nr 8, Warszawa 1988, ss. 47-52. 
[krótkie artykuły publikowane pod rozmaitymi pseudonimami w:] „Obserwator Wielkopolski”, Poznań 1983-1989, w tym wywiad przeprowadzony imiennie: Spychamy kulture na szary koniec; rozmowa ze Stanistawem Barańczakiem, „Obserwator Wielkopolski”, nr 135, Poznań 1989, ss. 4-5.

Tablice Zofii Lipeckiej, „Zeszyty Literackie”, R. VIII, nr 29, Paryż 1990, ss. 134-135.

Poza startem i meta, „Res Publica”, 1990, nr 11, s. 158.

The Poverty of the Avant-Garde, (w:) Center 10. Research Reports and Record of Activity, National Gallery of Art, Center for Advanced Studies in the Visual Arts, Washington D.C. 1990, ss. 67-68.

[wstęp do kat.] Popiak, Biuro Wystaw Artystycznych, Poznań 1991.

Dlaczego Poznań jest nudny [ankieta], „Gazeta Wyborcza”/,Gazeta Wielkopolska”, nr 239/108, 1991.

Rób Graffiti, „Gazeta Wyborcza”/,Gazeta Wielkopolska”, nr 251/119, 1991.

Fantastyczne lata pięćdziesiąte, „Gazeta Wyborcza”/,Gazeta Wielkopolska”, nr 256/124, 1991.

Notatki Profesora, „Gazeta Wyborcza”/,Gazeta Wielkopolska”, nr 273/ 141, 1991.

W kręgu dyskusji postmodernistycznych, „Artium Quaestiones”, V, Wydawnictwo Naukowe UAM, 1991, ss. 156-165.

Jakiej galerii poznaniacy potrzebuja, „Arkusz” [literacki miesięczny dodatek do: „Głos Wielkopolski”], nr 3, Poznań [23 styczeń] 1992.

Natura zawoskowana, „Arkusz”/,Głos Wielkopolski”, nr 5, Poznań [19 marzec] 1992.

[udział w dyskusji] Pojawi się nowe malarstwo, „Arkusz”/,Głos Wielkopolski”, nr 7, Poznań [21 maj] 1992.

Lyon w Łodzi, Łódź w Lyonie, „Odra”, Wrocław 1992, nr 10, ss. 86-88.

Mężczyzna idący do nieba, „Czas Kultury”, Poznań 1992, nr 6, ss. 4-9.

Włodzimierz Borowski; rewizja historii sztuki, „Odra”, Wrocław 1992, nr 12, ss. 93-94 „Galeria odNOWA”, Exit, Warszawa 1993, nr 2, ss. 594595.

[udział w dyskusji] Uświadamianie stereotypu, „Czas Kultury”, Poznań 1993, nr 2, ss. 66-69.

Czy Nowy Jork ukradt ideę wolności?, „Krytyka”, nr 41-42, Warszawa 1993, ss. 281-285. 
[wywiad] $O$ „Dekadzie” $i$ nie tylko, „Format”, nr 3-4 (12-13), 1993, ss. 111-113 [wywiad] Instalacje... w magazynie, „Dziennik Poznański”, Poznań 27.07.1994, s. 10 Zrozumieć Europę, „Nowy Nurt”, nr 17, 1994, ss. $13-14$.

Jarmark $z$ Reichstagiem, „Nowy Nurt”, nr 17, 1995, s. 16.

[o „Magazynie Sztuki”] w: Unter einen Dach. Polnische Galerien zu Gast im „Podewil”, Podewil, Berlin 1995, ss. 58-59.

Oś transeuropejska, „Nowy Nurt”, nr 1, 1996, ss. 14, 16.

Awangarda [hasło], (w:) Stownik terminologiczny sztuk pięknych (wydanie nowe), Warszawa 1996, ss. 27-28.

On the Road (wywiad), Balkon (Budapest), nr 6, 1996, ss. 32-35.

O powołaniach artysty i biskupa (wywiad), „Kresy”, nr 27, 1996, ss. $160-167$.

Historyczny wymiar odwilży/ The Historical Dimension of the Thaw (wywiad), „Magazyn Sztuki”, nr 11, 1996, ss. 36-58.

(Statement) (w:) Zur Problematik des Transformationsprozesses im künstelerischen Bereich.

Ein Vergleich zwischen den Erfahrungen von Kulturschaffenden und Kulturinstitutionen der DDR und Polen. Tagungsdokumentation, Weimar 1997, ss. 48-50.

(dyskusja) w: W cieniu krzesta. Malarstwo i sztuka przedmiotu Tadeusza Kantora, red. T. Gryglewicz, Instytut Historii Sztuki Uniwersytetu Jagiellońskiego, Kraków 1997, ss. 159, 164, 165-166.

Czy marginalizacja sztuki wspótczesnej? (dyskusja), „Format”, nr 26/ 27 (1-2), 1998, ss. 2-7.

Wytrącić z automatyzmu myślenia (wywiad), „Znak”, nr 12, 1998, ss. 60-68.

Zofia Kulik: sztuka krytyczna, „Pokaz”, 1999 (III kwartał), s. 41-42.

Sestavljanje zgodovine/ sestavljanje sodobnosti-Constructing a history/ constructing a contemporaneity", (w:) 2000+ ArtEast Collection. The Art of Eastern Europe in Dialogue with the West from the 1960 to the Present, Ljubljana: Moderne Galerija/ Museum of Modern Art, 2000, s. 22-29.

Co to jest Łódź Kaliska, „Gazeta Malarzy i Poetów”, 2000, nr 2 (34), s. 29-31.

Punkty widzenia. Spór o Zachętę. List, „Znak”, nr 4 (551), kwiecień 2001, 81-85. 
Krzywe lustra, „Gazeta Wyborcza”, 5.07.2001, 12.

Osobné spisy Jarosława Kozłowského, „Revue Svetovej Literatúry”, (Bratislava) No. 4, 2001, s. 169-171.

Nie przenoście nam historii na Morasko, „Gazeta Wyborcza”, Poznań, 1.03.2002, s. 18.

Irreligia i wyzwania wolności [dyskusja], „Gazeta Malarzy i Poetów”, Poznań, nr 1/2002, s. 5-9.

Sa rzeczy od awangardy ciekawsze [wywiad], „Pro Arte”, nr 16, 2002, s. 30-36.

Prowokuje, więc jestem, „Wprost”, 2003, nr 36, ss. 98-100; por. też: „Wprost”, 2003, nr 38, s. 9.

O wystawie „Poznań nowoczesny. Sztuka lat 1956-1964” [dyskusja], „Gazeta Malarzy i Poetów”, 2003, nr 5 (50), ss. 5-9.

Zofia Kulik, Rezonancie 2001, red. Zuzana Bartońová, Bratislava: AICA, 2003, ss. 68-72.

Wolność oka (wywiad), „Głos Wielkopolski”, 16.04.2004, s. VI.

Czy w Polsce toczy się wojna kulturowa. Dyskusja o cenzurze $i$ wolności sztuki, „Zeszyty Artystyczne”, Akademia Sztuk Pięknych, Poznań, nr 12 (czerwiec) 2004, ss. 7-26.

Round Table Discussion: How will the EU Expansion Affect Contemporary Art in the Central European Region, "Praesens. Central European Contemporary Art Review", Budapest, No. 2, 2004, ss. 27-44.

Dwie pokusy [wywiad], „Głos Wielkopolski”, 27.05.2005, s. C 11.

Les „cultural studies” en Pologne aujourd'hui, „Le Journal des Laboratoires", Aubervilliers, Juin-Dec, 2005, ss. 28-31.

Grać władzy na nosie [wywiad], „Gazeta Wyborcza”, Poznań, 25.08. 2005, s. 6.

Say what?, Interviu, Vilnius: „Contemporary Art Center”, 2005, No. 2.

Art History in Plural (wywiad), „Kontakt Magazine“, Wien, Issue 12, May 2006, http://kontakt.erstebankgroupe.net/magazine/issue12.

Krytycy potrzebni od zaraz, „Tygodnik Powszechny”, nr 37, Kraków, 16 września 2007, s. 21.

Iskustvo: V kvasidemokratichna sistema (wywiad), „Kultura” (Sofia, Bulgaria), 15 Juni 2007, s. 9.

Artysta między Leninem a Niņkiem (wywiad), „Przegląd Anarchistyczny", nr 6, 2007/ 2008, ss. 62-70.

Ślady/Traces, Boltanski (Chiński Portret/Chinese Portrait/ Le Portrait Chinois), red. M. Ślizińska, Warszawa: Centrum Sztuki Współczesnej „Zamek Ujazdowski” (2008) s. nienumerowane. 
Chiny. Uwagi osobiste, „Arteon”, nr 10, 2008, ss. 26-28.

A kep kritikaja, EX. Symposion, Budapest 2008, ss. 31-36.

Muzeum jako podmiot kultury demokratycznej (wywiad) „Obieg”, 11.03.2009, www.obieg.pl/rozmowy/9006

Społeczeństwo oswoiło się ze sztuka wspótczesna (wywiad), „Kresy”, nr (80) 4, 2009, ss. 183-187.

[Dorota Jarecka] Muzeum ma mieć siłe metropolii [rozmowa z prof. Piotrem Piotrowskim], „Gazeta Wyborcza”, 24.07.2009, s. 20.

[Krzysztof Lubczyński] Instytucja kultury krytycznej [wywiad z prof. dr. hab. Piotrem Piotrowskim, dyrektorem Muzeum Narodowego w Warszawie], „Trybuna”, nr 275 (6000), 24.11.2009, s. 8.

[Piotr Sarzyński] Ściagnę Delacroix do Warszawy [wywiad z prof. Piotrem Piotrowskim, dyrektorem Muzeum Narodowego w Warszawie], „Polityka”, nr 4 (2740), 23.01.2010, ss. 58-59.

[Dorota Jarecka] Konflikt w Narodowym [rozmowa z prof. Piotrem Piotrowskim], „Gazeta Wyborcza”, 7.07.2010, s. 10.

[Adam Mazur] Kryzys muzeów wedtug Piotra Piotrowskiego [„,0+21=1” \& „Insurance Policy”], wywiady, http://www.obieg.pl/19756 (13.12. 2010).

[Magdalena Radomska] Chcieliśmy otworzyć muzeum [wywiad], „Czas Kultury”, nr 5, 2010, ss. 90-99.

An Art Historian between the University and Museum. Towards the Idea of the Critical Museum, Index, Barcelona: MACBA, No. 0, 2010, ss. $12-15$.

http://www.artmargins.com/index.php/podcast/119-interviews/619-pi otr-piotrowski-resignation-polish-national-museum

Nationalisierte Avantgarden. Osteuropäsche Modernismen und der Mangel an Internationalität, Springerin, Winter 2011, ss. 27-29.

[Magdalena Ziółkowska] Muzeum krytyczne to nie dyskursywny ornament (rozmowa z Piotrem Piotrowskim) Dwutygodnik. Strona kultury, http://www.dwutygodnik.com.pl/artykul/2290-muzeum-krytyczne-to-niedyskursywny-ornament.html

Sztuka: czy Europa Środkowa istnieje/ Art: Does Central Europe exist, [moderator: K. Jagodzińska], Herito, Kraków, nr 4 (2011), ss. 78-93.

L'acritica del museo [interview - Pascal Dubourg-Glatigny], „Il Manifesto", nr 230, 28 Settembre 2011, ss. 10-11.

Edukacja muzealna może wygladać lepiej... [wywiad - Beata Niklewicz], „Polonistyka”, nr 11, grudzień 2011, ss. 58-61. 
Pokazujmy sztukę, która porusza [wywiad - Jacek Tamczuk], „Przekrój”, nr 42, 2011, s. 26.

Polityka w muzeum [wywiad - Jacek Maj], „Znak”, nr 4, 2012, ss. 96-99.

Provincializalni a Nyugatot, (wywiad - Edit Andras), Müértô, Budapest, Junius 2012, ss. 10-11. W języku angielskim: http://www.artmar gins.com/index.php/5-interviews/691-provincializing-the-west.

[komentarz w sprawie Muzeum Sztuki Nowoczesnej w Warszawie] Herito, nr 8, 2012, ss. 154-156.

Czy sztuka może nas uratować? O przedstawieniach Holocaustu, sztuce krytycznej i wspótczesnej humanistyce (z Ewą Domańską i Piotrem Piotrowskim rozmawia Jacek Leociak), „Zagłada Żydów”, nr 8, 2012, ss. 505-521.

Pojd'me mluvit o kriticke narodni identite. Roshovor s Piotrem Piotrowskim (wywiad), Ceska narodni identita v soućesnem umeni, Vysoka śkola umeleckoprumyslova, Praha, 2012, ss. 72-76.

Conceptual Art and Central Europe (Zdenka Badovinac, Eda Ćufer, Cristina Freire, Boris Groys, Charles Harrison, Vit Havranek, Piotr Piotrowski, Branca Stipanćić), Part I, e-flux, Journal \# 40, 12/ 2012; Part II, e-flux Journal \# 41, 1/2013 http://www.e-flux.com/journal/conceptual-artand-eastern-europe-part-i// http://www.e-flux.com/journal/conceptual-artand-eastern-europe-part-ii/.

Miłość do emancypacji [wywiad], „Widok”, Warszawa: IBL-PAN, nr 3, $2013 \mathrm{http}: / /$ widok.ibl.waw.pl/index.php/one/article/view/87/115.

East European Art from a Global Perspective (wywiad), Jahres bericht 2012/2013: - Neue Impulse für Area Studies, Regensburg: Graduiertenschule für Ost- und Südosteneuropastudien, 2014, ss. 56-61.

Róbmy strajk, profesorowie, „Gazeta Wyborcza”, 14-15.06.2014, s. 25.

A Way to Follow. Interview with Piotr Piotrowski, Richard Kosinsky, Jan Elantkowski, Barbara Dudás, ARTMargins, 29.01.2015, http:// www. artmargins.com/index.php/5-interviews/758-a-way-to-follow-interviewwith-piotr-piotrowski, wersja w języku polskim: Droga, która warto podazać. Rozmowa z Piotrem Piotrowskim. Richard Kosinsky, Jan Elantkowski, Barbara Dudás, tłum. Karolina Kolenda, „Obieg”, 30.03. 2015, http:// www.obieg.pl/teksty/35105. 